DOI: https://doi.org/10.24113/ijellh.v8i1.10402

\title{
Impact of slavery System in America with Reference to Colson Whitehead's the Underground Railroad.
}

\author{
Chellapandian. K \\ Research scholar in English \\ Govt Arts and Science College \\ Coimbatore, Tamil Nadu, India \\ chella.cb.co.in@gmail.com
}

\section{Abstract}

This article tells you that how the slavery system flourished in America and the impact of slavery system in America. Slavery system in America started when Christopher Columbus discovered America in the year 1492. In 1508 the first colony settlement was established by Ponce de Leon in Samjuan. The first African slaves arrived in South Carolina in 1526. During the 16th and 17th century the city St. Augustine was the Hub of the sla ve trade. Once Britishers established colonies in America, they started importing slaves from Africa. At one point Mary land and Virginia full of African slaves. After the discovery America Britishers came to know that America is suitable for cotton cultivation so they dawned with an idea that for cultivating cotton in America, Africans are the most eligible persons. On the other hand Britishers believed that Africans know the methods of cultivation and they are efficient labours. So they brought African through the Atlantic slave trade to work in cotton plantation. The amounts of slaves were greatly increased because of rapid expansion of the cotton industry. At the beginning of $17^{\text {th }}$ century Britishers were cultivating only cotton and later on they invented the cotton gin. The invention of the cotton gin demanded more manpower and 
DOI: https://doi.org/10.24113/ijellh.v8i1.10402

they started importing more slaves from Africa.At the same time southern part of America continued as slave societies and attempted to extend slavery into the western territories to keep their political share in the nation. During this time the United States became more polarized over the issue of slavery split into slaves and free states. Due to this in Virginia and Maryland a new community of African and American culture developed. As the United States expanded southern states, have to maintain a balance between the number slave and free state to maintain political power in the united states senate.

In 1808 various states passed different restrictions on the international slave trade this promoted illegal slave trade through Spanish Florida. The cotton crop was labor intensive and least costly labors were slaves. Slaves were never cheap if they were productive. The slaveholders could freely and legally use them as sexual objects. The used a term FANCY LADIES for a woman who is suitable for sexual use. Enslaved people were considered as properties and transported from Maryland, Virginia hundred miles south to retain them as most efficient labours. Slaves were served as America's largest financial asset. Those slaves who did not meet their target were beaten violently. They used the slaves as their tools and made considerable development in the world's economy. This novel was written beautifully but with fulls of tears. It shines a bright light on the dark side of the history.

Colson's novel under railroad depicts that the cruelty which was faced by the black people before the civil war. At one point number of slaves were increased in America, there came the realization. They were sold not only work, but also for sexual pleasures. Colson could not bear this ill-treatment of his class people. Though this was a recorded in history, he was humiliated and so he wrote this novel with his patriotic spirit to reach a wider audience. How a mother could not bear the sufferings of his child like that Colson did in this novel. We might have read all these with historical perspective, not in this view. Every slave had a dream of escaping. This novel influences, Tony Morrison's 'Beloved'. 
DOI: https://doi.org/10.24113/ijellh.v8i1.10402

Colson begins his novel with the story of the Ajary grandmother of his heroine Cora and gradually he brought out brutality of heartless whites. From Ajary to her daughter Mabel and Cora all were the elements of the slavery this show that how they have been ill-treated by them. Cora escapes with Caesar they were captured and tortured. Cora rises from underground Railroad in the world of body snatchers and abolitionist. When she wanted to flee from the bonds she failed and she was attacked by the slave catchers. Throu gh his novel Colson said that racial discrimination was the main cause for the slavery. Blacks were constantly ill-treated. He considers this novel as a medium of salvation. Colson white head exhibits his anguish through his novels like the Underground Railroad and zone one nickel boys. In nickel boys Ellwood was tutored by his grandmother and grew as a brilliant boy. She taught him we are not inferior to whites'. This shows that after the Second World War in 1962 also racial discrimination prevailed. He was attracted by Martin Luther king's speech and he had an interest in civil rights movements. When he was a child, he used to visit the hotels of whites where his mother and grandmother were working. There he read encyclopedia this made him wise. Accidently when he went to nickel academy there he got support from the instructor of the academy. What he noticed in the society was inequality this infuriates him to participate in the civil rights movement. Though they were equal in physical and mental capacities they were constantly subjugated. In order to establish a peaceful life for their class they rose against whites. The brutalities which were faced by them were countless.

When African were under the Britishers were not allowed to think about their freedom by separating them from their families and behave violently. As a result of slave trade cotton production and America's economy greatly increased and Southern Planters increased their per capita than any other region. Slave trade transformed the America's economy. 
DOI: https://doi.org/10.24113/ijellh.v8i1.10402

Africans were unaware of their unity and strength and so they were treated as slaves.

They have been waiting for a representative who can give them freedom. A long waited problem came to an end when Abraham Lincoln came to existence. 
DOI: https://doi.org/10.24113/ijellh.v8i1.10402

References

Colson Whitehead's, The Underground Railroad, Doubledday, published August 2, 2016.

The intuitionist

Nickel boys 